Revista Brasileira de Agricultura Irrigada v.8, no. 2, p. 127 - 138, 2014

ISSN 1982-7679 (On-line)

Fortaleza, CE, INOVAGRI - http://www.inovagri.org.br

DOI: $10.7127 /$ rbai.v8n200231

Protocolo 231/14 - 12/09/2013 Aprovado em 18/03/2014

\title{
ESTIMATES FOR MAIZE YIELD (Zea mays L.) IN RAINFED AND IRRIGATED CROPS DETERMINED BY THE METHOD OF AGROECOLOGICAL ZONE/FAO (ZAE/FAO), STATE OF ALAGOAS, BRAZIL
}

Remy Farias de Souza ${ }^{1}$, Allan Cunha Barros ${ }^{2}$, Alexandre Hugo Cezar Barros ${ }^{3}$, José Nildo Tabosa $^{4}$

\begin{abstract}
The aimed of this study was to calibrate the model ZAE/FAO and estimate productivity, assessing which planting periods have lower risks to maize crop in the state of Alagoas. The study was conducted at the Universidade Federal de Alagoas, in partnership with Embrapa Solos - unit Recife - PE and Instituto Agronômico de Pernambuco - IPA - PE, developed in two stages: ZAE/FAO model calibration with maize yield data obtained from the Maize Breeding Program-NE region, municipality of Araripina - PE, after calibration, scenarios were simulated for the municipalities: Arapiraca, Água Branca, Palmeira dos Índios and Porto de Pedras, obtaining yields based on the planting season (every ten days) whose CAD (19,5 $58,5-65,0 \mathrm{~mm}) \times$ cropping system (irrigated and rainfed). In calibration, the ZAE/FAO method presented "optimum"statistical performance indexes for the reliability index $(\mathrm{CI}=$ 0,86). The highest yield was achieved for the municipalities of Arapiraca 5.099 and $8.748 \mathrm{~kg}$ $\mathrm{ha}^{-1}$, now in the municipalities of Palmeira dos Indios, with the lowest yields were 2.308 and $4.711 \mathrm{~kg} \mathrm{ha}^{-1}$ respectively in the non-irrigated and irrigated condition. On average irrigated yields were $58 \%$ higher than non-irrigated. In the irrigated system is recommended planting maize at any time and in the months from march to may, rainiest months.
\end{abstract}

Keywords: agricultural prediction, food security, water balance.

\section{ESTIMATIVAS DE PRODUTIVIDADE PARA MILHO (Zea mays L.) EM SEQUEIRO E IRRIGADO DETERMINADA PELO MÉTODO DA ZONA AGROECOLÓGICA/FAO (ZAE/FAO), ESTADO DE ALAGOAS, BRASIL}

\section{RESUMO}

\footnotetext{
${ }^{1}$ Part of the dissertation of the first author, Eng. Agronomist, Marter's, Arapiraca/UFAL, CEP 57300 - 970, Email: remyfarias@ hotmail.com

${ }^{2}$ Teacher by Univerdade Federal de Alagoas, Arapiraca/UFAL, 57309-005 - Arapiraca, AL - Brasil. E-mail: Allan.cunha.barros@gmail.com

${ }^{3}$ Researcher at Embrapa Soils, unit Recife-Pernambuco. Empresa Brasileira de Pesquisa Agropecuária, Centro Nacional de Pesquisa de Solos, Uep Recife. 50020-240 - Rio de Janeiro, RJ - Brasil. E-mail: alex.hugo.2006@gmail.com

${ }^{4}$ Researcher at Instituto Agronômico State of Pernambuco - IPA. 50761-000 - Recife, PE - Brasil - Caixa-postal: 1022 E-mail: nildo.tabosa@ipa.br
} 
O propósito deste estudo foi calibrar o modelo ZAE/FAO e estimar produtividade, avaliando quais épocas de plantio apresentam menores riscos a cultura do milho no Estado de Alagoas. O estudo foi desenvolvido na Universidade Federal de Alagoas, em parceria com Embrapa Solos e o Instituto Agronômico de Pernambuco - IPA - PE, desenvolvido em duas etapas: calibração do modelo ZAE/FAO com dados de produtividade de milho, obtidos do Programa de melhoramento Genético de Milho da região NE, município de Araripina - PE e a etapa seguinte foi simular produtividade do milho para os municípios: Arapiraca, Água Branca, Palmeira dos Índios e Porto de Pedras, no seguintes cenários: com base na época de plantio (a cada dez dias) cuja CADs (19,5 - 58,5-65,0 mm) x sistema de plantio (irrigado e sequeiro). $\mathrm{Na}$ calibração o Método ZAE/FAO apresentou índices de desempenho estatístico "otimo" para índice confiabilidade $(\mathrm{IC}=0,86)$ As maiores produtividades alcançadas foi para $\mathrm{o}$ município de Arapiraca com 5.099 e $8.748 \mathrm{~kg} \mathrm{ha}^{-1}$, já o município de Palmeira dos Índios, ficou com as menores produtividades 2.308 e $4.711 \mathrm{~kg} \mathrm{ha}^{-1}$ respectivamente na condição não irrigada e irrigada. Em média as produtividades irrigadas foram, 58\% maiores que as não irrigadas. No sistema irrigado recomenda-se o plantio do milho em qualquer época e em sequeiro nos meses de março - maio, meses mais chuvosos.

Palavras-chave: predição agrícola, segurança alimentar, balanço hídrico.

\section{INTRODUCTION}

Agricultural production of food, fibers and bio-energy is related to conditions of climate and soil (FRANCHINI et al., 2012). Agricultural productivity is reflection of climatic conditions such as rainfall, evapotranspiration, and the chemical and physical characteristics of soils that vary according to texture, structure and degree of pedological development, as well as the type of treatment used, thus the available water capacity in ground related to water balance in crops is dependent on the dynamics of the soil-plantatmosphere (WAGNER et al., 2013).

Maize produced in the Brazilian Northeast (NE) cultivated between march and june, the rainy season, with water supply capable of keeping the crop at a desired level without necessarily waive irrigation, used in a complementary manner by a few producers, who are most familiar and essentially use the upland handling, characterized by the use of low technology combined with the irregular rainfall affecting production (SILVA et al., 2011; SOUZA et al., 2011; WAGNER et al., 2013).

Faced with climate instability in the NE region, it is important to producers in decisionmaking and to countries in creating range policies to agriculture obtaining information that anticipates results relating to agricultural productivity. Thus, the use of modeling through the information generated is a smart option; the models can simulate productivity of several 
crops in a range of edaphoclimatic scenarios (NEAMOTOLLAHI et al., 2012; BACENETTI et al., 2014).

Muniz et al. (2007) high light as positive the application of modeling for producing predictions of particular interest aiming at making decisions and operating a production system; contribution to the development of climatic zoning and providing theoretical basis for future studies.

The use of models is wide in agriculture and with infinity applications, Barros et al. (2005) simulated the limiting effect of nutrients in the production, Mello \& Silva (2009); Gaiser et al. (2010) made use of modeling in the development and yield of maize under varying conditions of climate and soil in tropical regions; Barros et al. (2013) estimated waterphysical attributes of some soil classes.

The simulations related to the soils and climate scenarios are based on two types of models, one related to scientific knowledge of agricultural crops and their interactions with environments, scientific or mechanistic models; another based on empirical relationships between plants and their interactions with environmental variables, called engineering or functional models (PASSIOURA, 1996).

The ZAE/FAO method estimates the maximum crop yield and it is considered a scientific or mechanistic model, because the methodology is basically ecophysiological, with the application of crop-related parameters such as leaf area index, harvest index, gross production of dry matter and climate data (solar radiation, temperature, rainfall and evapotranspiration) (SANTOS et al., 2011). Several authors have used the ZAE method to estimate productivity (KASSAM, 1977; FISCHER et al., 2002; DENG et al., 2006). Thus, the objective was to calibrate the ZAE model and estimate yield, assessing which planting periods have lower climate risks to maize in some municipalities in the state of Alagoas.

\section{MATERIAL AND METHODS}

The study has been developed in partnership between the Federal University of Alagoas, Campus Arapiraca and Embrapa Solos, Unit Recife, Pernambuco state. Two stages were developed: the first with ZAE/FAO calibration for maize crop and the second with simulations for maize yield in the municipalities of the state of Alagoas, municipalities of Arapiraca, Água Branca, Palmeiras dos Índios and Porto de Pedras. The calibration step will be described ahead.

The municipalities of Palmeiras dos Índios and Arapiraca have typical climate of harsh rainy region, with dry summer, the rainy season starts in february with completion in september and annual rainfall around $1.634 \mathrm{~mm}$. The municipality of Água Branca, the climate is tropical semi-arid with summer rains, the rainy season starts in november 
ending in april, with annual mean rainfall of 431,80 $\mathrm{mm}$, typical of semiarid regions worldide. Finally, the municipality of Porto de Pedras with Rainy Tropical type climate with dry summer, the rainy season begins in the fall starting in february and ending in october, with annual rainfallof $1.634,2 \mathrm{~mm}$ (CPRM, 2005) .

The model described by Doorenbos \& Kassam (1994) in the FAO's manual 33, describes the ZAE method developed by Kassam Doorenbos \& Kassam (1979) to estimate the maximum cropyield that is based on the concepts of De Wit (1965). Such a prediction method for maximum productivity was developed with continental scope. However, Oliveira et al. (2002) indicate its use in smaller scales, adjusted to a level of local detail. Martins (2012) used the method for estimating productivity of maize and sorghum in the NE region, obtaining satisfactory results.

The ZAE is calculated by the following equation (1):

$Y m p=c L \times c N \times G[F(a+b \times y m) y o+(1-F)(c+d \times y m) y(])$

Where: Ymp - refers to the maximum potential crop productivity $\left(\mathrm{kg} \mathrm{ha}^{-1} \mathrm{day}^{-1}\right)$ and the correction coefficients for the crop; cL - correction depending on the crop development and leaf area; $\mathrm{cN}-$ correction for dry matter production; $\mathrm{cH}$ - correction for the harvested part; $\mathrm{G}$ - total growth period (day); F - day shift when the sun is obscured by clouds; ym - rate of dry matter production of leaves $\left(\mathrm{kg} \mathrm{ha}^{-1}\right.$ day $^{-}$ ${ }^{1}$ ); yc - comprises the gross production rate of dry matter $\left(\mathrm{kg} \mathrm{ha}^{-1}\right.$ period $\left.^{-1}\right)$ and the values a, b, c and $\mathrm{d}$ are coefficients of the equation that were equal to 0,$8 ; 0,01 ; 0,5$ and 0,025 respectively for $\mathrm{Yc} \geq 20 \mathrm{~kg}$ $\mathrm{ha}^{-1} \mathrm{day}^{-1}$ such condition being treated. The $\mathrm{F}$ value is obtained by the equation (2):

$$
F=\left(\frac{R s o \times 0,5 \times R s}{0,8 \times R s o}\right)
$$

Where: Rso - solar irradiance on the surface for clear days, $\mathrm{MJ} \mathrm{m}^{-2} \mathrm{~d}^{-1}$; Rs - global solar irradiance on the surface were transformed from $\mathrm{MJ} \mathrm{m}{ }^{-2}$ day $^{-1}$ to $\mathrm{Cal}$ $\mathrm{m}^{-2} \mathrm{day}^{-1}$ for being used as productivity model of Agroecological Zone (Doorembos \& Kassaam, 1979).

The accounting of actual productivity ( $\mathrm{Yr}$ ) is carried out by correlating the crop growth with consumption, boosted by the yield depreciation factor due to drought (Ky), which may vary according to crop and phenological phases.

To estimate the Yr, the model uses the Ymp as input data calculated by the ZAE method, the crop's response coefficient, the total evapotranspiration and total maximum crop evapotranspiration during its cycle (OLIVEIRA et al., 2010). Thus, the $\mathrm{Yr}$ is calculated by the equation (3):

$$
Y r=\operatorname{Ymp}\left\lfloor 1-k y\left(1-\frac{E T r}{E T p}\right)\right\rfloor
$$

Where: Yr - actual crop yield (t ha-1); Ky - empirical coefficient is the crop sensitivity to drought; ETr crop evapotranspiration (mm); ETp - maximum crop evapotranspiration $(\mathrm{mm})$. 
The ETo was calculated according to PenmanMoneith (Allen et al. 1998) and the ETP was calculated by equation (4):

$$
E T p=E T o \times K c
$$

Where: ETp - maximum crop evapotranspiration $\left(\mathrm{mm}\right.$ day $\left.^{-1}\right)$; ETo - reference evapotranspiration $(\mathrm{mm}$ day $\left.^{-1}\right) ; \mathrm{Kc}-$ crop coefficient. Kc values were used: I (0.4), II (1.1), III (0.88) and IV (0.58), corresponding to growth, flowering, grain formation and maturation that are the phenological stages of culture.

To determine the ETr was used the coefficient of water stress - Ks penalizes the plant water consumption due to soil water deficits, equation (5):

$$
K s=\frac{\ln [L R A+1]}{\ln [C T A+1]}
$$

Where: LRA - water depth in the soil (mm); CTA soil water total capacity (mm).

Then it was estimated the ETR through equation (6):

$$
E T r=E T o \times K c \times K s
$$

Model calibration was based on 11 years of maize yields collected from the Breeding Program of Maize in Northeast region of Araripina - PE, assigned by the Instituto Agronômico de Pernambuco - IPA. Data were the same used by Barros (2010) and Martins (2012), who used the
ZAE method to predict productivity of maize crop in these regions.

In the process of model calibration was necessary to enter data on soil and climate. The soil data were collected from Barros (2010) and consisted primarily of values of Field capacity, wilt point (based on volume - $\Theta$ ) and soil density, the climate data were provided by the Intituto Nacional de Meteorologia - INMET namely: minimm and maximum temperature, rainfall, solar radiation and reference evapotranspiration, recommended by the FAO bulletin 56 (Allen et al. 2001), values from the municipality of Araripina - PE $\left(7,48^{\circ} \mathrm{S}, 40,60^{\circ} \mathrm{W}\right.$ and 622,0 m altitude).

The values for $\mathrm{cL}, \mathrm{cN}, \mathrm{cH}, \mathrm{Ym}$ were modified until the estimated values were the closest as possible to those observed, for such the visual method was used. Calibrations were also subjected to statistical analyses to assess the quality of the simulations.

Statistical analyses used to calibrate were the statistical tests commonly used in the literature with appropriate modeling: Pearson correlation coefficient (r) corresponding to the precision that is the approaching of estimated results, Willmott "d" Coefficient (Willmott et al., 1985) includes accuracy, which is the proximity to the true value or accepted, mean error square root (MESR) and confidence index (CI) Camargo \& Sentelhas (1997), which is the product of precision with accuracy; thus, the more accurate and precise the estimated data the greater confidence in the estimated productivity; following the formulas of equations 7 , 8, 9 and 10: 


$$
r=\frac{N \sum x y-\left(\sum x\right)\left(\sum y\right)}{\sqrt{\left[N \sum_{x} 2-\left(\sum_{x} 2\right)\right]\left[N \sum_{y} 2-\left(\sum_{y} 2\right)\right]}}
$$

Where: $\mathrm{x}$ - observed value; $\mathrm{y}$ - estimated value and $\mathrm{n}$ - number of observations.

$$
d=1-\frac{\sum_{i-1}^{n}(P i-O i)^{2}}{\sum_{i=1}^{N}[(|P i-\bar{O}|)+(|O i-\bar{O}|)]^{2}}
$$

Where: $\mathrm{Pi}$ - simulated productivity $\left(\mathrm{kg} \mathrm{ha}^{-1}\right)$; Oi observed productivity $\left(\mathrm{kg} \mathrm{ha}^{-1}\right)$.

$$
R M S E=\sqrt{\frac{\sum_{i=1}^{n}(y-x)^{2}}{n}} \quad \frac{100}{\bar{x}}
$$

$$
I C=r \times d
$$

The statistical indices achieved in the calibration were framed in the category of "optimum" statistical performance, indicated by the confidence index $(\mathrm{CI}=0.86)$ that involves the correctness or accuracy, represented by the Willmott coefficient that also reached "optimum" level $(\mathrm{d}=$ 0.95) and accuracy, represented by the Pearson correlation coefficient, indicating correlation $(\mathrm{r}=$ $0.90)$, an indicative of success of the method (ZAE) among yields estimated that well correlated the yields observed, ending with the difference between the observations and simulations assigned to the Medium Error (RMSE) classified as "acceptable" $(\mathrm{RMSE}=21.7 \%)$.
For simulation of scenarios was used climate data from the cities of Arapiraca, Água Branca, Palmeiras dos Índios and Porto de Pedras collected by the National Institute of Meteorology - IMET. It was adopted as the depth of crop root system as $0.15,0.45$ and $0.5 \mathrm{~m}$ for phenological crop stages, I, II, III - IV.

The scenarios of simulation in obtaining yields based on planting dates (with intervals of 10 days for each simulation practiced) with the following capabilities soil water storage CADs soil $(19,5$ - 58,5 and $650, \mathrm{~mm}) \mathrm{X}$ planting system (irrigated and rainfed), in 6,0 scenarios each simulated for year, being used 11 years * 37 simulations / year to the cities of Água Branca and Palmeiras dos Índios 5 years * 37 simulations / year to Porto de Pedras and 3 years old * 37 simulations / year to Arapiraca, getting 1.110 simulations * 2 planting system (irrigated and rainfed), totaling 2.220 simulations.

The simulated average productivity data were analyzed using descriptive statistics in order to obtain the dispersion through thr standard deviation (s) and coefficient of variation $(\mathrm{CV})$.

\section{RESULTS AND DISCUSSION}

The table 1 shows the years and yields estimated and obseerved used in the ZAE model calibration as well as their differences, there was overestimation and the difference found was $550 \mathrm{~kg}$ $\mathrm{ha}^{-1}$. The years 1991/1992/1993 and 1997/1998 showed low observed yields, justified by the El Niño phenomenon that warms the waters of the Equatorial 
Pacific Ocean; El Niño was rated strong intensity in those years, associated with moderate to severe drought; however, when the El Niño showed weak intensity, the years 2002/2003 and 2005/2006 had their productivity increased (MOLION \& BERNARDO, 2002; MARTINS, 2011; MINUZZI \& RIBEIRO, 2012).

According to Table 2, the highest yields estimated were due to water availability adequate to 440 to $600 \mathrm{~mm}$ (FANCELLI, 2000; MAGALHÃES \& DURÃES, 2006). The municipatity of Arapiraca showed the highest yield $5.099 \mathrm{~kg} \mathrm{ha}^{-1}$ when grown on dryland, followed by Porto de Pedras $3.554 \mathrm{~kg} \mathrm{ha}{ }^{-1}$, there being realtionship with the absence of water in the tasseling period to the early grain filling, which can cause reduction in productivity or total loss (LYRA et al., 2010).

The municipality of Palmeira dos Indios had the lowest mean in this study $2.307 \mathrm{~kg} \mathrm{ha}^{-1}$, considered the lower productivity of rainfed crop in the state; however, well above the state mean in 2012/2013 crop estimated at $754 \mathrm{~kg} \mathrm{ha}^{-1}$ Conab (2013), the largest volumes of mean rainfall are concentrated from march to may, august and september, the water availability offered by irregular rainfall in the states of $\mathrm{NE}$ region is considered a limiting factor in agriculture in semi-arid regions, and it has been considered the main characteristic of the maize-growing regions around the world (BERGAMASCHI et al., 2004; SAMPAIO et al., 2012; WAGNER et al., 2013).

In the irrigated condition, the city of Arapiraca reached the highest level with $8.748 \mathrm{~kg}$ $\mathrm{ha}^{-1}$, similar mean the largest maize-producing regions in the country (BERGAMASCHI et al., 2004 and 2006; CONAB, 2013; WAGNER et al., 2013). The municipalities of Água Branca, Palmeira dos Índios and Porto de Pedras under irrigated condition showed means far below the Arapiraca; however, values close to the national mean of 4.961 $\mathrm{kg} \mathrm{ha}^{-1}$ (CONAB, 2013).

The set of estimated average productivity in rainfed and irrigated for municipalities evaluated (Figure 1) show that under rainfed crop, the highest yield occurred predominantly in the first half of the year, reaching their peaks between from March to May, when managed under irrigation, the distribution of means were nearly uniform throughout the year (LYRA et al., 2010; ALVES et al., 2011).

Figure 1 also shows the average productivity related to the rainfall and solar radiation, the maize under irrigated crop was influenced by the photosynthetically active radiation (PAR) comprised in the frequency range of 0,4 to $0,7 \mu \mathrm{m}$, once the water availability was supplied to the need (ASSIS et al., 2006). This frequency of radiation provides the energy from the sun responsible for heating the air and soil, water evaporation and absorption of $\mathrm{CO}_{2}$ relative to photosynthesis; thus, it is important in gas exchange, and therefore decisive in the formation of carbohydrates and hence agricultural productivity (GUSMÃO et al., 2012). Bergamaschi et al. (2010) argue that the maize crop under irrigated conditions showed $20 \%$ more use of RFA. In the rainfall observations, several studies assert their influence in yields when maize grown is in rainfed leading to a dispersive behavior relative to the mean value (MELLO \& SILVA, 
2009; GAISER et al., 2010; ALVES et al., 2011; BENIN et al., 2013).

This fact is explained in the CV values found in rainfed and irrigated shown in Table 2, which corresponds to the data accuracy on the monthly yields, representing the standard deviation expressed as percentage scale aiming at showing the dispersions and also making it possible to compare the remaining studies.

The means from irrigated crops had higher accuracy compared to rainfed cultivation since rainfall are notevenly distributed in dryland to a normal behavior, naturally occurring variations, interfering around the mean, according to the high CV in the rainfed crop (MOUSINHO et al., 2006; BAÚ et al., 2013). Thus, a CV considered high does not represent the ZA Emethod quality, but it represents the data distribution of climatic data, especially rainfall, used in the model input (GARCIA, 1989).

When the crop was irrigated, means productivity behaved with interference of rainfall in the municipalities of Porto de Pedras and Palmeira dos Indios; the ZAE Method did not show the same behavior for the municipality of Água Branca and Arapiraca, Mello \& Silva, (2009) suggest observing other variables that could be input in the model in order to respond to rainfall.

\section{CONCLUSIONS}

1. The ZAE/FAO method showed accuracy considered excellent in the calibration step $(\mathrm{CI}=$ $0,86)$.
2. The highest yield was achieved for the municipalities of Arapiraca 5.099 and $8.748 \mathrm{~kg} \mathrm{ha}^{-1}$, now in the municipalities of Palmeira dos Indios, with the lowest yields were 2.308 and $4.711 \mathrm{~kg} \mathrm{ha}^{-1}$ respectively in the non-irrigated and irrigated condition, the irrigation promoted $58 \%$ increment on mean productivity.

3. Planting in irrigated condition is recommended at any time, the planting season most suitable for upland condition is the rainy season, especially from March to May.

Table 1. Productivity observed and estimated for the municipality of Araripina, state of Pernambuco, used in the step of model calibration.

$$
\text { Productivity }\left(\mathrm{kg} \mathrm{ha}^{-1}\right)
$$

Yars $\quad 19941995199619992000200120022003200420052006$ Mean

Observed 3.9003 .5305 .8714 .7344 .7752 .9114 .1115 .3022 .6114 .6515 .9194 .287

Estimated 5.9004 .1655 .2855 .7323 .7774 .0143 .0215 .8465 .0934 .1186 .9044 .812

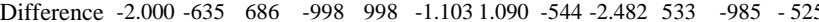

Table 2. Mean yields estimated for municipalities of Alagoas.

\begin{tabular}{ccccc}
\hline \multicolumn{5}{c}{ Productivity rainfed $\left(\mathrm{kg} \mathrm{há}^{-1}\right)$} \\
\hline $\begin{array}{c}\text { Statiscal } \\
\text { decription }\end{array}$ & $\begin{array}{c}\text { Água } \\
\text { Branca }\end{array}$ & Arapiraca & $\begin{array}{c}\text { Palmeira } \\
\text { dos } \\
\text { Índios }\end{array}$ & $\begin{array}{c}\text { Porto } \\
\text { de } \\
\text { Pedras }\end{array}$ \\
$\overline{\mathrm{x}}$ & 2.439 & 5.099 & 2.308 & 3.554 \\
$\mathrm{~S}$ & 815 & 1.711 & 932 & 885 \\
$\mathrm{CV}$ & 33 & 34 & 40 & 25 \\
\hline \multicolumn{5}{c}{ Productivity irrigated $\left(\mathrm{kg} \mathrm{há}^{-1}\right)$} \\
\hline$\overline{\mathrm{x}}$ & 4.713 & 8.748 & 4.711 & 4.920 \\
$\mathrm{~S}$ & 941 & 593 & 889 & 295 \\
$\mathrm{CV}$ & 20 & 7 & 19 & 6 \\
\hline
\end{tabular}



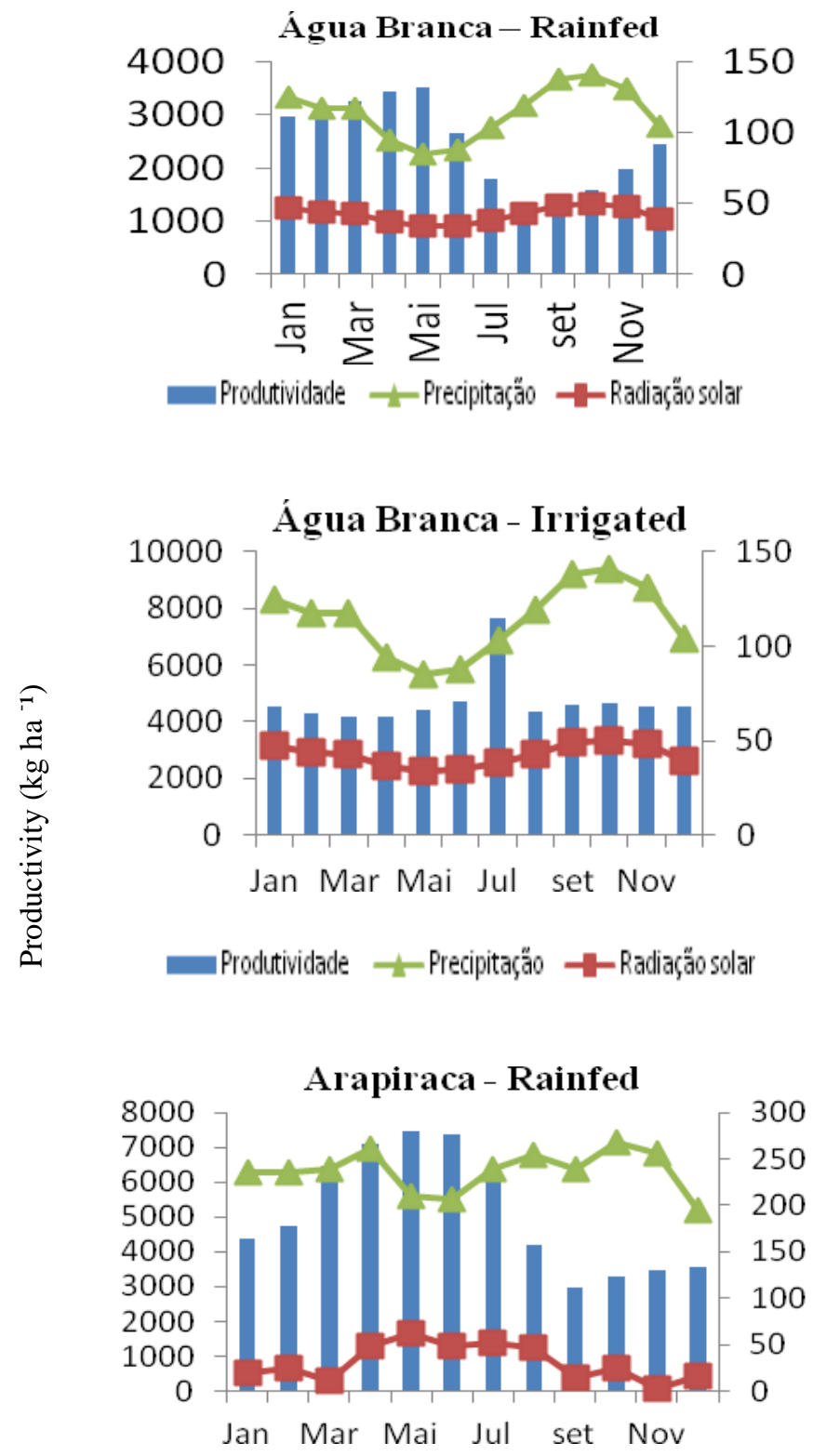

Produtividade - -Precipitação - -Radiação solar

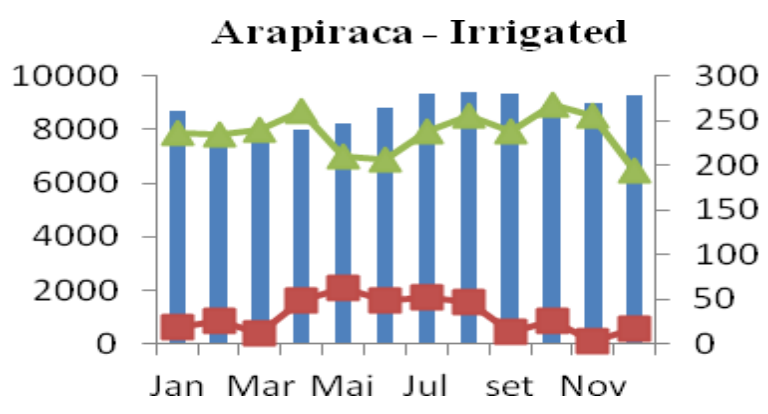

Produtividade - Precipitação - -Radiação solar

\section{Palmeira dos Índios - Rainfed}

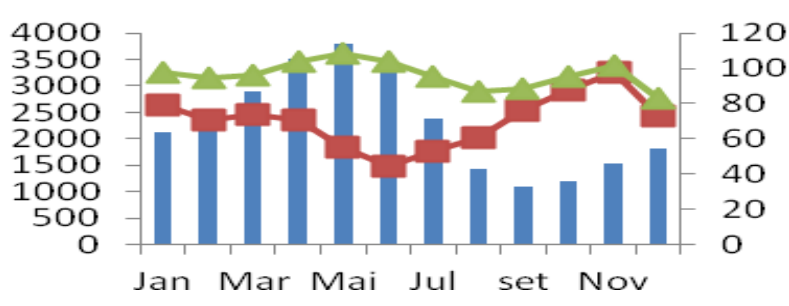

Produtividade - -Precipitaçăo - -Radiaçăo solar

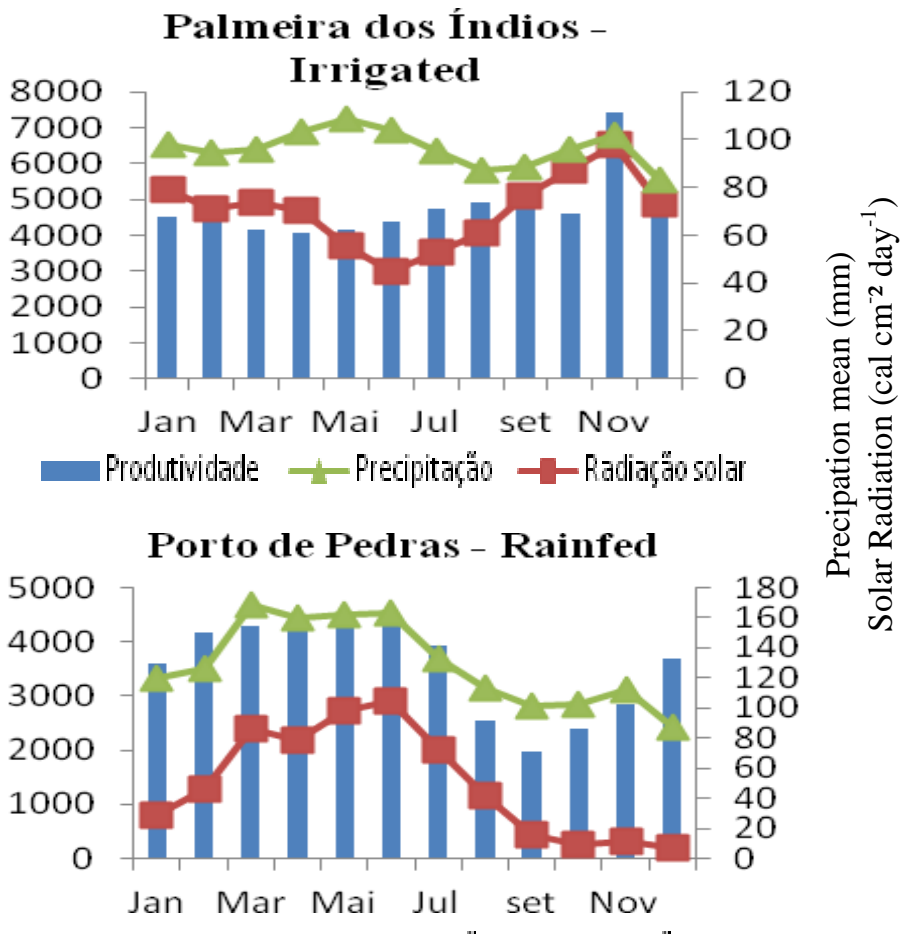

Porto de Pedras - irrigated

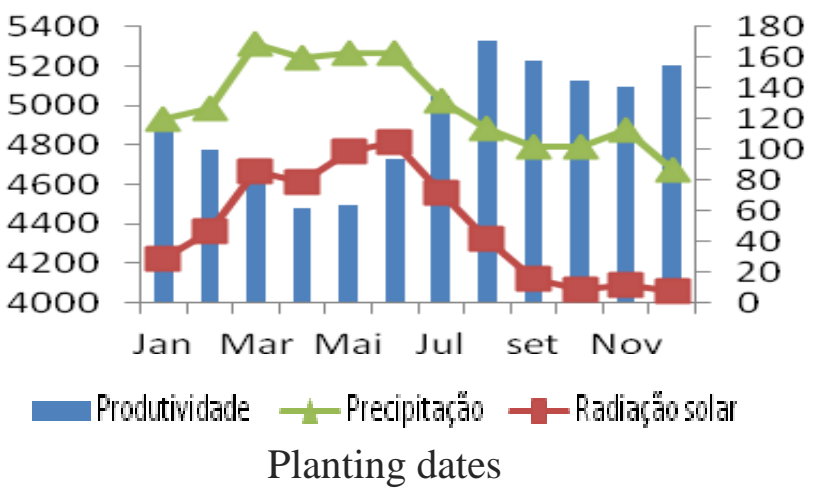

Figure 1. Means of productivity estimated on the basis of precipitation and solar radiation grown in rainfed and irrigated. 


\section{BIBLIOGRAPHICAL REFERENCES}

ALVES, M.E.B.; ANDRADE, C.L.T.; CÁRDENAS, R.R.; AMARAL, T.A.; SILVA, D.F. Identificação e quantificação do efeito de fatores ambientais na produtividade da cultura do milho na região de Janaúba, MG. Revista Brasileira de Agricultura Irrigada, v. 5, $\mathrm{n}^{\circ} .3$, p. $188-201$, 2011.

ASSIS, J.P.A.; DOURADO NETO, D.; REICHARDT, K.; MANFROM, P.A.; MARTIN, T.N.; BONNECARRÈRE, R.A.C. Dados climáticos simulados e produtividade potencial de milho. Resvista Pesquisa Agropecuária Brasileira, v. 14, n.5, p. $731-737,2006$.

BACENETTI, J.; FUSI, A.; NEGRI, M.; GUIDETTI, R.; FIALA, M. Environmental assessment of two crop systems in term the biomethane potencial production. Journal Science of the Total Environment, p.1066 - 1077, 2014.

BARROS, A.H. C.; LIER, Q.G.V.; MAIA, A.H.N.; SCARPARE, F.V. Pedrotrasnfer functions to to estimate water retention parameters of soils in Northeast Brazil. Revista Brasileira de Ciência do Solo, v.37, p.379 - 391, 2013.

BARROS, I.; WILLIANS, J.R.; GAISER, T. Modeling of nutrient limitations to crop production in semiarid NE of Brazil with a modified EPIC version II: Field test of the model. Journal Ecological Modelling, v.181, p.567 - 580, 2005.

BAÚ, A. L.; AZEVEDO, C. A. V.; BRESOLIN, A. A. Modelagem da precipitação pluvial diária intraanual da Bacia Hidrográfica Paraná III associada aos eventos ENOS. Revista Brasileira de Engenharia Agrícola e Ambiental, v. 17, n. 8, 2013.

BENIN, G.; STORCK, L.; MARCHIORO, V.S.; FRANCO, F.A.; SCHUSTER, I. Precisão experimental em ensaios de trigo em regiões homogêneas de adaptação. Revista Pesquisa Agropecuária brasileira. V.48, n.4, p.365-372, 2013.

BERGAMASCHI, H.; DALMAGO, G.A.; BERGONCI, J.I.; BIANCHI, C.A.M.; MÜLLER, A.G.; COMIRAN, F.; HECKLER, B.M.M.
Distribuição hídrica no período critico do milho e produção de grãos. Revista Pesquisa Agropecuária Brasileira, v.39, p.831 - 839, 2004.

BERGAMASCHI, H.; DALMAGO, G.A.; BERGONCI, J.I.; KRÜGER, C.A.M.B.; HECKLER, B.M. M.; COMIRAN, F. Intercepted solar radiation by maize crops subjected to different tillage systems and water availability levels. Pesq. agropec. bras., , v.45, n.12, p.1331-1341, 2010.

BERGAMASCHI, H.; DALMAGO, G.A.; COMIRAN, F.; BERGONCI, J.I.; MÜLLER, A.G.; FRANÇA, S.; SANTOS, A.O.; RADIN, B.; BIANCHI, C.A.M.; PEREIRA, P.G.Deficit hídrico e produtividade na cultura do milho. Revista Pesquisa Agropecuária Brasileira, v.41, n.2, 243 - 249, 2006.

CAMARGO, A.P.; SENTELHAS, P.C. Avaliação do desempenho de diferentes métodos de estimativa de evapotranspiração potencial no Estado de são Paulo. Revista Brasileira de agrometeorologia, v.5, n.1, p. 89 - 97, 1997.

COMPANHIA

NACIONAL DE ABASTECIMENTO. Acompanhamento de safra brasileira: grãos, nono levantamento, junho 2013 /Companhia Nacional de Abastecimento. Brasília: Conab, 2013.

De Wit C.T. Photosynthesis of Leaf Canopies. Centre for Agricultural Publications and Documentation, Wageningen, 57 pp. 1965.

DENG, X.; HUANG, J.; ROZELLE, S.; UCHIDA, E. Cultivated land conversion and potential agricultural productivity in China. Land use Policy, v.23, p.372-384, 2006.

DOORENBOS, J.; KASSAN, A.H. BENTVELSEN, C.L.M.; BRANSCHEID， V.; PLUSJÉ，J.M.G.A.; SMITH, M.; UITTENBOGARARD, G.O.; VAN DER WALL, H.K. Yeld response to water. Rome: FAO, 1979. 193 P. ( Irrigation and Drainage Paper, $33)$.

FANCELLI, A. L.; DOURADO NETO, D. Produção de milho. Guaíba: Agropecuária, 2000. 360p. 
FISCHER, G.; VELTHUIZEN, H.V.; SHAH, M.; NACHTERGAELE, F.O. Global agro-ecological assessment for agriculture in the 21 st century: Methodology and results. ILASA RR -02-02, IIASA, Laxenburg, 2002.

FRANCHINI, J.C.; DEBIASI, H.; BALBINOTE JUNIOR, A.A.; TONON, B.C.; FARIAS, J.R.B.; OLIVEIRA, M.C.N.;TORRES, E. Evolution of crop yields in different systems over two decades in Southern Brazil. Paper Field Crops Research, V. 137, P, 178-185, 2012.

GAISER, T.; BARROS, I.; SEREKE, F.; LANGE, F.M. Validation and reliability of the Epic model to simulate maize production in Small-Holder farming systems in tropical sub-humid West Africa and semi-arid Brazil. Agriculture, Ecosystems and Environment, v. 135, p. 318-327, 2010.

GARCIA, C.H. Tabelas para classificação do coeficiente de variação. IPEF - Instituto de Pesquisa e Estudos Florestais. Circular técnico n 171. Esalq, 1989.

GUSMÃO ， A.C.V.L.; SILVA, B.B.; MONTENEGRO, S.M.G.L.; GALVÍNCIO, J.D. Determinação do saldo radiativo na Ilha do Bananal - To, com imagens orbitais. Revista brasileira de Engenharia Agrícola e Ambiental. V.16, n.10, p.1107-1114, 2012.

KASSAM, A.H. Net biomass production and yield of crops. Present and potential land use by agroecological zones project. Rome, FAO. 1977.

LYRA, G.B.; SOUZA, J.L; TEODORO, I.; LYRA, G.B.; MOURA FILHO, G.; ARAÚJO JÚNIOR, R.F. Cobertura de água no solo em cultivo de milho sem e com cobertura morta na entrelinha na região de Arapiraca - Al. Revista Irriga, v. 15, n. 2, p. 173 $-183,2010$.

MARTINS, J. A.; DALLACORT, R.; INOUE, M.H.; GALVANIN, E.A.S; MAGNANI, E.B.Z.; OLIVEIRA, K.C. Caracterização do regime pluviométrico no arco das nascentes do Rio Paraguai. Revista brasileira de meteorologia, V.26, N.4, 639 - 647, 2011.
MAGALHÂES, P.C.; DURÃES, F.O.M. Fisiologia da produção do milho. Circular técnico 76. Embrapa Milho e Sorgo, 2006.

MELLO, C.R.; SILVA, A.M. Modelagem estatística da precipitação mensal e anual e no período seco para o estado de Minas Gerais. Revista Brasileira de Egenharia Agrícola e Ambiental, v.13, n.1, p.68-74, 2009.

MINUZZI, R.B.; RIBEIRO, A.J. Requerimento de água para irrigação do milho em Santa Catarina durante eventos La Niña. Revista brasileira de Engenharia Agrícola e Ambiental, v.16, n.12, p.1330-1337, 2012.

MOUSINHO, F.E.P.; ANDRADE JÚNIOR, A.S.; GONÇALVES, A.C.A.; FRIZZONE, J.A. Variabilidade espacial dos percentis 75 da precipitação pluvial anual para os Estado Piaú. Irriga, v.11, n. 2, p. 178 - 187, 2006.

MOLION, L.C.B.; BERNADO, S.O. Uma revisão da dinâmica das chuvas no Nordeste Brasileiro. Revista Brasileira de Meteorologia, v.17, n.1, p. 210, 2002.

MUNIZ, L.C.; VIU, M.A.O.; MAGANABOSCO, C.U,; LOPES, D.T. Modelagem e simulação na agropecuária. Revista Pubvet, v. 1, n. 11, 2007.

NEAMATOLLAHI, E.; BANNAYAN, M.; JAHANSUZ, M.R.; STRUIK, P.; FARID, A. Agroecological zoning for wheat (Triticum aestivum), sugar beet (Beta vulgaris) and corn (Zea mays) on the Mashhad plain, Khorasan Rasavi province. The Egyptian Journal of Remote Sensing and Space Sciences, v.15, p.99-112, 2012.

OLIVEIRA, H.F. de. Avaliação de modelos de estimativa de produtividade da cana-de-açúcar irrigada em Jaíba-MG. Viçosa-MG, 2010. 96p. Dissertação (Mestrado em Meteorologia Agrícola) Universidade Federal de Viçosa, UFV.

OLIVEIRA, J.S.; FERREIRA, R.P.; CRUZ, C.D. et al. Adaptabilidade e estabilidade em cultivares de sorgo. Revista Brasileira de Zootecnia, v.31, n.2, p.883-889, 2002. 
SANTOS, M.M.; GALVÃO, J.C.C.; MELO, A.V.; ADRIANO, R.C.; FIDELIS, R.R.; CORRÊA, M.L.P. Efeito da fonte de nitrogênio e da época de aplicação na cultura do milho, em plantio direto, com espaçamento reduzido. Revista brasileira de milho e sorgo, v.10, n.1, p.29-37, 2011.

SILVA, A.S.; SILVA, I.F.; SILVA NETO, L.F.; SOUZA, C. Semeadura direta na produção de milho em agricultura de sequeiro na região Nordeste do Brasil. Revista Ciência Rural, v.41, n.9, p.1556 1562, 2011.

SOUZA, L.S.B.; MOURA, M.S.B.; SEDIYAMA, G.C.; SILVA, T.G.F. Eficiência no uso da água das culturas do milho e do feijão-caupi sob diferentes sistemas de plantio exclusivo e consorciado no semiárido brasileiro. Revista Bragantia, v.70, n.3, p.715 - 721, 2011.

WAGNER, M.V.; JADOSKI, S.O.; MAGGI, M.F.;SAITO, L.R.; LIMA, A.S. Estimativa da produtividade do milho em função da disponibilidade hídrica em Guarapuava, PR, Brasil. Revista brasileira de Engenharia Agrícola e Ambiental, v. 17, n.2, p. 170-179, 2013.

WILLMOTT, C.J.; ACKLESON, S.G.; DAVIES, R.E.; FEDDEMA, J.J.; KLINK, K.M.; LEGATES, D.R.; O'DONNELL, J.; ROWE, C.M. Statistics for the evaluation and comparison of models. Journal of Geophysical Research, v.90, p. 8995-9005, 1985 . 